I. ENVIRONMENTAL BIOTECHNOLOGY

\title{
DEVELOPMENT OF NOVEL UNIVERSAL BIOTECHNOLOGIES FOR OBTAINING VALUABLE PRODUCTS FROM A WIDE RANGE OF WASTES
}

\author{
Oleksandr Tashyrev, Vira Hovorukha, Valery Shevel, Olesia Havryliuk, Iryna Sioma
}

\begin{abstract}
Despite the achievements in development of environmental biotechnologies, the total amount of waste is continuously increasing. Development of novel methodological approach is the only possible effective solution of problems. The aim was to develop the base of universal biotechnologies for effective treatment of all four classes of waste and obtain valuable products. To obtain biotechnologically promising results the method of thermodynamic prognosis of microbial interaction with toxic compounds (multi component food waste and filtrate, metal containing wastewater, radioactive waste) was developed. The following results of food waste degradation were obtained: time detention $T=6$ days, coefficient of waste destruction $K d=90$; biohydrogen yield $120 \mathrm{~L}$ from $1 \mathrm{~kg}$ of waste. Wastewater treatment provided purification from 10020 to $20 \mathrm{ppm}$ of total Carbon and toxic metals. Purification of liquid radioactive waste allowed several orders decreasing its activity within 4-5 days. These biotechnologies are promising for their industrial implementation in order to stop pollution of environment and preserve ecosystems.
\end{abstract}

Keywords: thermodynamic prognosis, environmental biotechnologies, biohydrogen, toxic metals, radioactive waste.

\section{INTRODUCTION}

There are several problems in the sphere of environment protection that do not have an effective solution in the world scale at present time. They include: 1. processing of huge volumes of multi component food waste (MCFW) of megacities; 2. purification of toxic food waste filtrates (FWF); 3. purification metalcontaining wastewater (MCWW); 4. purification of liquid radioactive waste (LRW).

Food waste of megacities is the most environmentally dangerous component of urban waste $[14,23,56]$. The composition of food waste includes concentrated polymeric compounds of plant and animal origin. Unlike paper, cardboard, plastic, they are natural compounds and therefore they begin to rot within a couple of days. This is manifested in the spontaneous decay of polymers with the formation of whole spectrum of toxic liquid and gaseous products (fatty acids, alcohols, ammonia, hydrogen sulfide, mercaptans, etc.) [27, 28, 85]. Modern physico-chemical and other biotechnologies do not provide effective neutralization of MCFW, since their processing speed is much lower than the speed of their accumulation $[6,38,49,54,56]$. The technologies of disposal and vermicomposting require a large area for waste utilization [56]. In addition, earthworms are very sensitive to changes in $\mathrm{pH}$, temperature and water content of the medium and toxic products of putrefaction of waste cause their death, which leads to inevitable interruption of the utilization process [54]. Methods of thermal utilization, including hydrothermal carbonization not only require significant energy costs, but also lead to the release of toxic gaseous products into the environment $[38,49]$.

The toxic food waste filtrate is an integral part of food waste. The FWF contains of concentrated alcohols and fatty acids, which suppress methanogenic microorganisms in the concentration of $180-520 \mathrm{ppm}$ (1.6-4.6 mM) [35] and also some Clostridium species at $10-150 \mathrm{ppm}$ [1]. The creation of landfills, even in so-called isolated geological formations, does not allow avoiding filtration and toxic compounds entering the environment. In addition, there are significant difficulties in studying of contaminant transport parameters and the service life of clay (mineral) barriers, drainage layers, geosynthetics, and the main features of the waste $[11,12]$.

Effective technologies (physico-chemical and biological) for purification of metal-containing wastewater (MCWW) are developed at industrial scale $[3,18,24,34,39,40,42,44-47,51,55,61,62 ; 78,81]$. However, purification of the MCWW of mining industrial complexes has not yet been resolved at the world level [21]. The reason of this is the enormous volumes of such MCWW [ 30], as well as a wide range of toxic metals in sewage $\left(\mathrm{Hg}^{2+}, \mathrm{Cd}^{2+}, \mathrm{Co}^{2+}, \mathrm{Ni}^{2+}\right.$ etc. $)$ [16].

Liquid radioactive waste (LRW) from mining enterprises is even more dangerous pollutants. Such wastewater contains a wide range of associated toxic metals in addition to radioactive elements [26, 57]. Obviously, such LRW cannot be recycled. Unfortunately, this problem is universally hushed up, both in scientific literature and in the media. Also, purification of the water areas of ecosystems in the 
zone of nuclear disasters should be attributed to strategically important problems that have no solution now. Huge territories contaminated with radionuclides in the area of the Chernobyl nuclear power plant and Fukushima are the examples. The huge volume of radioactive water is also a great problem of purification of such type of water areas [19, 57].

Despite numerous attempts to find a way out of the appeared methodological deadlock, the volume of these four types of waste is continuously increasing in the world [14, 23, 30, 26, 56, 57]. In our opinion, the lack of effective methodological approach is the reason for such a deplorable state of industrial environmental technologies.

Therefore, the aim of the work was to describe the theoretical approach for development of universal biotechnologies that effectively treat all four types of waste and obtain valuable products.

\section{MATERIALS AND METHODS}

Processing of huge volumes of multi component food waste of megacities

Effectiveness of processing of multi component food waste was tested using anaerobic batch reactor (volume of working chamber $-20 \mathrm{~L}$ ). Mixture of raw and boiled potatoes, raw tomatoes, cucumbers, zucchini, cabbage, carrots, apples, parsley, chicken fillet, boiled pasta, bread in equal weight ratio was used as model substrate. The following components were loaded to the reactor $2.0 \mathrm{~kg}$ of $10 \mathrm{~min}$. pasteurized multi component food waste; $6.0 \mathrm{~L}$ of tap $10 \mathrm{~min}$. boiled, and cooled to $35^{\circ} \mathrm{C}$ water; $1 \%$ of microbial inoculum; $140.0 \mathrm{~g} \mathrm{CaCO}_{3}$. Saturated solution of $\mathrm{Na}_{2} \mathrm{CO}_{3}$ was added periodically to the reactor during fermentation to provide optimal values of $\mathrm{pH}$. Operating period of fermentation was 7 days at temperature $30^{\circ} \mathrm{C}$. The $\mathrm{pH}$, Eh, volume and composition of gas were controlled [63].

Completion of fermentation cycle was evaluated visually by full destruction of waste particles, termination of gas synthesis, decrease in concentration of $\mathrm{H}_{2}$.

The following fermentation parameters of were determined: 1$)$ duration of operating period ( $T$, days); 2 ) molecular hydrogen yield (L); 3) coefficient of waste destruction $(K d)$ [63].

\section{Purification of toxic food waste filtrate}

Efficiency of toxic food waste filtrate purification was investigated on model organic sewage (concentration of organics counting to total Carbon was 10020 ppm) in modular pilot plant. It consisted of 10 sections. First seven ones were used for anaerobic fermentation of organic compounds of filtrate. The last three were intensively aerated and provided aerobic post treatment of traces of organics in solution. The effectiveness of organic sewage purification was controlled using the method of permanganate titration $[60,65]$.

Purification of metal-containing wastewater

For investigation of the possibility of microorganisms to remove metals from wastewater metabolically active microbial communities and strains isolated from natural ecosystems were used. Microbial resistance to toxic metals $\left(\mathrm{Cr}(\mathrm{VI}), \mathrm{Hg}^{2+}, \mathrm{Cu}^{2+}\right)$ in high concentrations was tested using metal containing nutrient media. Then the possibility of metal resistant microorganisms to remove toxic metals form solution was confirmed [52, 67, 68, 72, 73].

Purification of liquid radioactive waste

Purification of wastewater from radionuclides was carried out at the Institute for Nuclear Research of the National Academy of Sciences. Developed granulated microbial pellets loaded in purification columns provided reduction in activity of the following radionuclides: ${ }^{51} \mathrm{Cr},{ }^{54} \mathrm{Mn},{ }^{60} \mathrm{Co},{ }^{83} \mathrm{Rb},{ }^{90} \mathrm{Sr},{ }^{137} \mathrm{Cs},{ }^{140} \mathrm{La}$, ${ }^{144} \mathrm{Ce},{ }^{226} \mathrm{Ra},{ }^{238} \mathrm{U},{ }^{239} \mathrm{Pu},{ }^{241} \mathrm{Am}[70,74,75]$.

Development of combined waste treatment biotechnology

Combined technology was tested using integrated approaches of simultaneous fermentation of organic compounds [63] and microbial reduction of soluble $\mathrm{CrO}_{4}{ }^{2-}$ to insoluble chromium(III) hydroxide $\mathrm{Cr}(\mathrm{OH})_{3} \cdot \mathrm{nH}_{2} \mathrm{O}[72]$.

\section{RESULTS AND DISCUSSION}

First of all, it should be noted that we consider described wastes classes as extreme factors in relation to microorganisms and ecosystems (Fig. 1).

Our assessment of 4 types of toxic compounds as extreme factors opens the way for understandable and simple method of justification and selection of optimal waste treatment biotechnology (Fig. 1). So, on the basis of thermodynamic prognosis (Fig. 1, point 1 ) theoretically permissible chemical reactions (Fig. 1, point 2) are considered. As the result, a toxic compound is destroyed (destruction, insoluble compounds formation, etc.). Then the most effective reaction is selected. Then optimal path, among the pathways known for microorganisms is selected (Fig. 1, point 3). Obviously, the selected pathway of toxic compounds detoxification may carry out a number of different physiological and taxonomic groups of microorganisms. The next step is the theoretical justification to choose the optimal microbial community (Fig. 1, point 4) and further obtaining of microbial culture, carrying out the detoxification of extreme factor. Regularities of microbial treatment of extreme factor are studied at laboratory scale. The obtained data are used to 
optimize the biotechnological process in the pilot project (Fig. 1, point 5). Obtained biotechnological indicators are further used for the implementation of pilot industrial and industrial biotechnology (Fig. 1, point 6). The final step is to achieve a stable detoxification effect for each of the 4 classes of industrial waste (extreme factors) or bioremediation of contaminated ecosystems (Fig. 1, point 7).

Obtaining of useful valuable end products (ecologically pure energy carrier - $\mathrm{H}_{2}$, metal concentrate, purified water, etc.) is the distinctive feature of our biotechnologies (Fig. 1, point 8).

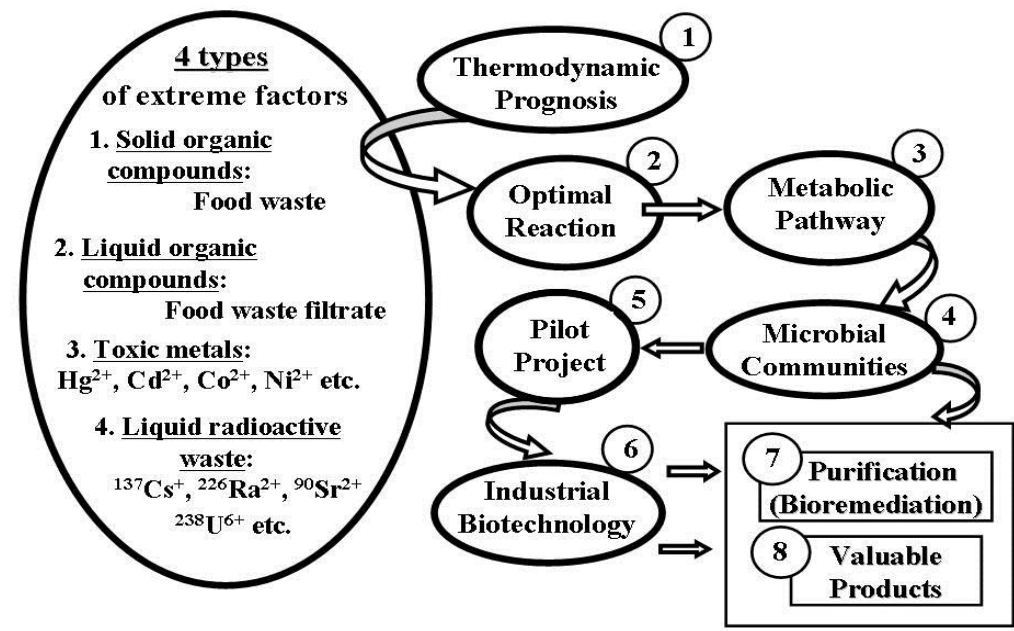

Fig. 1. Types of extreme factors for microorganisms and ecosystems

Let's consider sequentially each of detoxification stages of toxic compounds (extreme factors). First of all, consideration of toxic compounds as extreme factors immediately leads to the idea of determining the maximum permissible concentrations of each of the factors for microorganisms (microbial communities). This radically changes the methodological approach. Instead of random, empirical selection of microorganisms, somehow interacting with toxicant, we find a logical and methodologically simple approach.
Processing of huge volumes of multi component food waste of megacities

From the point of view of thermodynamics and chemical kinetics, the aerobic destruction of MCFW is excluded. The reason is inevitable deficiency of the terminal electron acceptor $\left(\mathrm{O}_{2}\right)$ in relation to the donor - concentrated polymeric compounds in a binary donor-acceptor reaction. Therefore, the destruction of solid organic compounds in the absence of external acceptors $\left(\mathrm{NO}^{3-}, \mathrm{SO}_{4}{ }^{2-}\right.$, etc.) is theoretically permissible and justified. Disproportionation reactions are acceptable. In this case, the molecule of the polymer is simultaneously reduced and oxidized:

$$
\begin{aligned}
& {\left[\mathrm{C}_{6} \mathrm{H}_{12} \mathrm{O}_{6}\right]_{\mathrm{n}} \rightarrow \mathrm{nC}_{6} \mathrm{H}_{12} \mathrm{O}_{6} \ldots \rightarrow \mathrm{C}_{6} \mathrm{H}_{12} \mathrm{O}_{6} \rightarrow \mathrm{CH}_{3} \mathrm{COOH}+6 \mathrm{H}_{2}+6 \mathrm{CO}_{2}(\Delta \mathrm{G}=-184 \mathrm{~kJ} / \mathrm{M})} \\
& \text { reduced oxidized }
\end{aligned}
$$

$$
\begin{aligned}
{\left[\mathrm{C}_{6} \mathrm{H}_{12} \mathrm{O}_{6}\right]_{\mathrm{m}} \rightarrow \ldots \mathrm{mHCOOH} \ldots \rightarrow 4 \mathrm{HCOOH} } & \rightarrow \mathrm{CH}_{4}+\mathrm{CO}_{2}+2 \mathrm{H}_{2} \mathrm{O}(\Delta \mathrm{G}=-130 \mathrm{~kJ} / \mathrm{M}) \\
& \text { reduced oxidized }
\end{aligned}
$$

Obviously, such reactions are optimal for destruction of solid organic compounds, since they are not limited by the terminal electron acceptor. Therefore, they are indispensable for the destruction of MCFW. Destruction of solid organic waste along the path of disproportionation is achieved during hydrogen and methane fermentation.

Considering the metabolic pathways of hydrogen or methane fermentation it is evident that the first is the most suitable. Thus, methane fermentation is long-termed (30 days), since it is carried out in 4 consecutive phases (formation of anaerobic conditions, acid hydrolysis, formation of methanogenesis precursors, methanogenesis) [82, 83]. In addition, during metanogenesis, exquisite exometabolites are formed: hydrogen sulphide, mercaptans, etc. Hydrogen fermentation of solid substrates is carried out in one phase and quickly (3-7 days) $[36,53,63]$ with the formation of an ecologically pure and high-energy carrier -molecular hydrogen, and carbon dioxide. Hydrogen sulphide and mercaptans are not formed. 
Thermodynamic prognosis allowed achieving fast and efficient MCFW hydrogen fermentation [4, 63] (Fig. 2). Thus, $120 \mathrm{~L}$ of $\mathrm{H}_{2}$ was synthesized from each kilogram of waste for 6 days. Coefficient of waste destruction (ratio of initial and final waste weight) was very high, $\mathrm{Kd}=90$ [63].

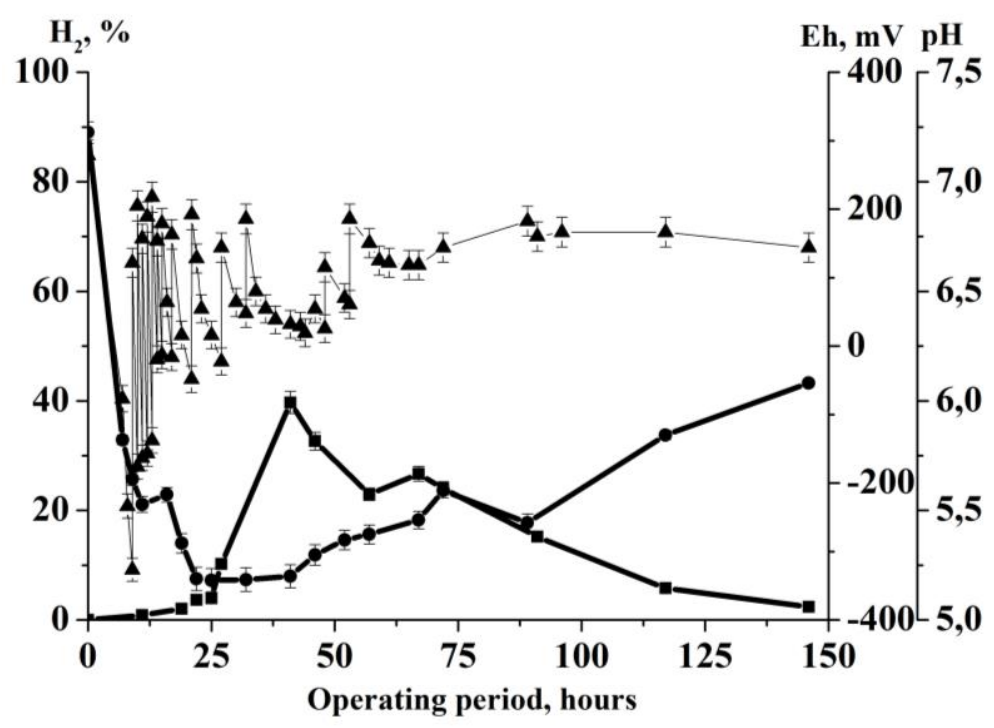

Fig. 2. High effectiveness of optimized hydrogen dark fermentation

Of course, this reaction was most effectively carried out by community of "primary anaerobes" hydrolyzing a wide range of organic compounds. This approach was successfully confirmed during destruction of multi component food waste at Ukrainian Antarctic Station "Academic Vernadsky" [64].

Currently, a low hydrogen yield is disadvantage of many food waste fermentation biotechnologies [33, 79]. Wang showed that only 65 liters of $\mathrm{H}_{2}$ from the kilogram of waste $\mathrm{kg}^{-1}$ vs were obtained during fermentation of food waste [79]. Attempts have already been made to optimize hydrogen fermentation of food waste for increase hydrogen yield. However, optimization of only one metabolic parameter does not lead to significant increase in hydrogen yield. Thus, when processing food waste, the base increased the yield of hydrogen to only $62.6 \mathrm{~mL} \mathrm{H}_{2} / \mathrm{g}^{-1}$ vs, which corresponds to $62.61 \mathrm{of}_{2} / \mathrm{kg}$ waste [33]. Much more hydrogen is synthesized after a complex optimization of the process of fermentation of food waste. Thus, with synchronous regulation of $\mathrm{pH}, \mathrm{Eh}$, mixing mode, etc., hydrogen yield can be doubled up to $123 \mathrm{~L} / \mathrm{kg}$ of waste [63].

Higher yield of hydrogen can be obtained. However, this metabolic parametr is determined by the composition of waste that acts as a substrate for microorganisms. Thus, during hydrogen fermentation of a rice suspension, which may consist $65-80 \%$ of starch and sugars [15], $356 \mathrm{~L} \mathrm{H}_{2} / \mathrm{g}$-carbohydrate was obtained [17]. However, this composition of waste is far from the actual composition of the huge volumes of continuously accumulating food waste in the world $[14,56,23]$. We investigated multi component food waste as close to real household waste as possible. They contained the remains of fresh and spoiled vegetables (potatoes, tomatoes, carrots, etc.), fruits, as well as meat and bakery products. According to theoretical calculations, the composition of carbohydrates in them does not exceed $10 \%$.

\section{Purification of toxic food waste filtrate}

Concentrated solution of wide range of organic compounds in FWF is the second type of extreme factors (toxic compounds). It is characterized by the same feature as for solid food waste - the unacceptability of aerobic destruction (see paragraph 1). Obviously, the same approach and the same microorganisms must be used for fast and effective fermentation, as for the destruction of MCFW [66] (Fig. 3).

The effectiveness of our approach was confirmed by purification of concentrated filtrates $(10020 \mathrm{ppm}$ COD). The filtrate was purified in a flow installation, consisting of 10 sections. In sections 1-7 (Fig. 3) anaerobic destruction of FWF occurred due to the absence of forced aeration, and the concentration of compounds decreased by $70-80 \%$ (up to $2000-3000$ ppm). On this the possibility of anaerobic destruction was exhausted, since the final products of metabolism accumulated in the medium, and inhibited the process by the feedback mechanism. Therefore, complete organic compounds destruction was achieved under 
aerobic conditions. During intensive bubbling of FWF by air, microbial end metabolites (fatty acids, alcohols, etc.) were destroyed to the final compounds
$\mathrm{CO}_{2}$ and $\mathrm{H}_{2} \mathrm{O}$. The trace concentration of organic compounds did not exceed $20-50 \mathrm{ppm}$ of total Carbon [66].

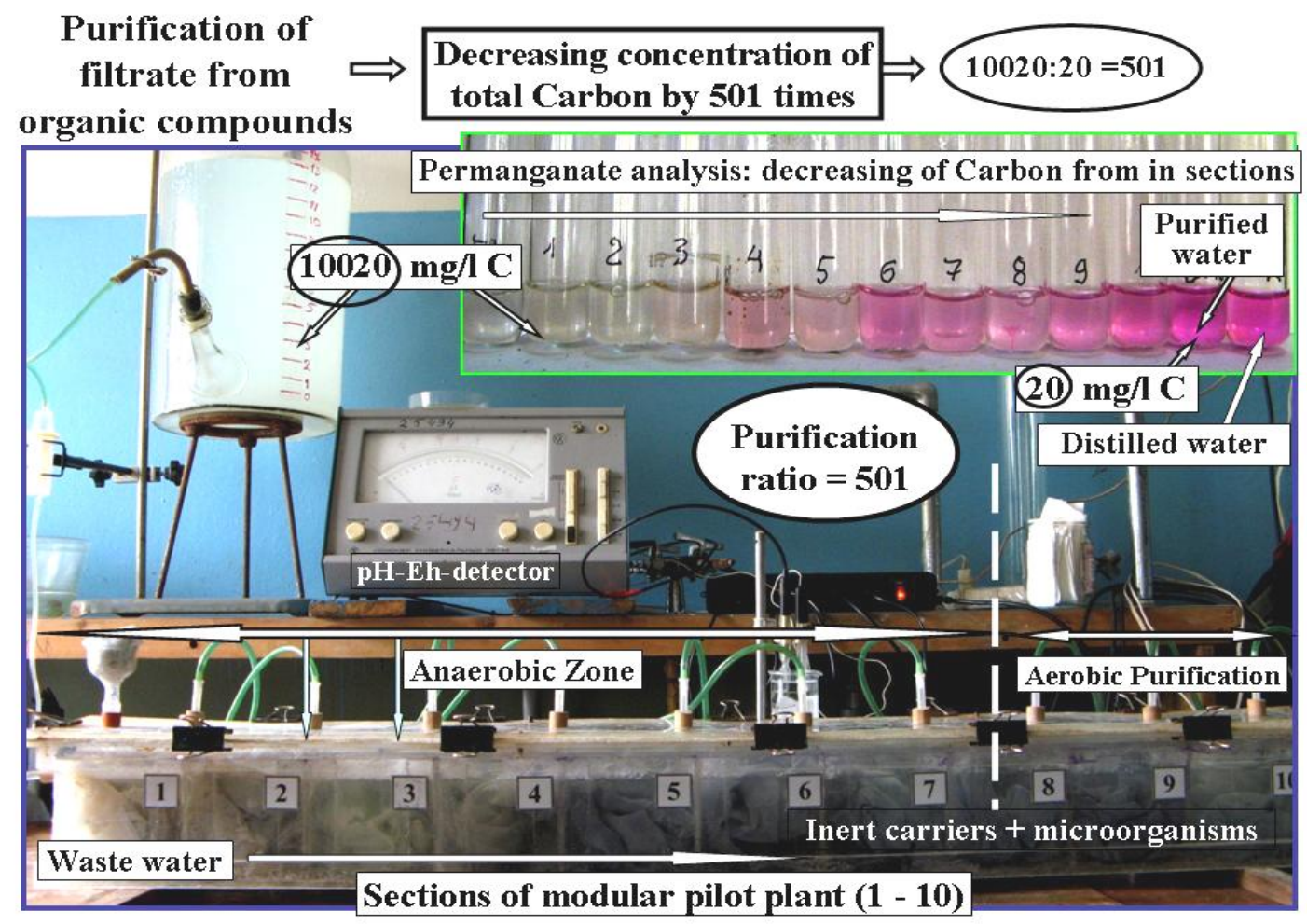

Fig. 3. Effectiveness of purification of toxic food waste filtrates

At present, various physico-chemical methods of ozonization, sorption, etc., are used to remove organic compounds from food waste $[8,25]$. However, these methods are energetically costly, and the purification efficiency is much lower than during biological destruction [32, 66, 84]. Thus, Zong also demonstrated two-step biological process of removal of organic compounds combining dark fermentation and photo-fermentation. Meanwhile, the COD decreased greatly with a removal efficiency of $84 \%$ in cassava batch and $80 \%$ in food waste batch [84].

\section{Purification of metal-containing wastewater}

The most difficult problem to overcome is the purification of metal-containing wastewater (MCWW). They include dozens of toxic metals in the form of ions $\mathrm{CAg}^{+}, \mathrm{Au}^{3+}, \mathrm{Hg}^{2+}, \mathrm{Cu}^{2+}, \mathrm{Cd}^{2+}, \mathrm{Co}^{2+}, \mathrm{Ni}^{2+}, \mathrm{Pb}^{2+}$, $\mathrm{CrO}_{4}{ }^{2-}, \mathrm{VO}_{3}{ }^{-}, \mathrm{CrO}_{4}{ }^{2-}, \mathrm{MoO}_{4}{ }^{2-}$, etc.). Each of metals has specificity of toxic effects on microorganisms. In addition, the removal of toxic metals from wastewater requires simultaneous implementation of various metabolic pathways: reduction to insoluble compounds, precipitation of metals by exometabolites, sorption, etc. That is why it is difficult to develop an effective biotechnology for purification of MCWW.

On the basis of thermodynamic prediction of interaction of microorganisms with metals, we have identified two main directions. The first one is the prediction of microbial reduction of a wide range of metals to insoluble compounds. All metals of the periodic system of elements are divided into two groups. The first group is metals that can be reduced by microorganisms (Fig. 4), the second group is metals, the reduction of which has thermodynamic prohibition. Microbial reduction of metals has a nonspecific character, i.e. it is carried out by microorganisms that are not adapted to metals. Admissibility and effectiveness of reactions is determined only by the potential difference between electron donor (metabolically active microorganisms) and acceptor (oxidized metal) (Fig. 4) [67]. 


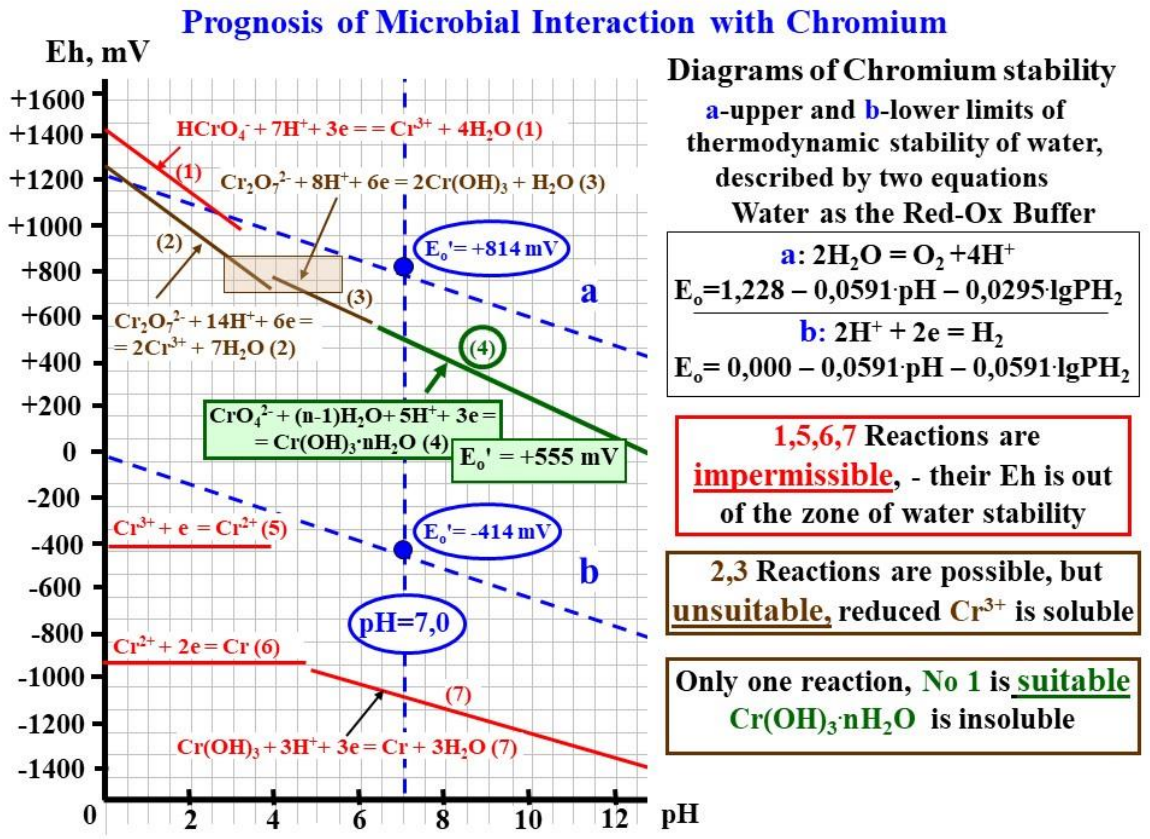

Fig. 4. Thermodynamic prognosis of microbial interaction with chromium compounds

The second group is metals, the reduction of which is thermodynamically prohibited $\left(\mathrm{Hg}^{2+}, \mathrm{Cu}^{2+}\right.$, $\left.\mathrm{Cd}^{2+}, \mathrm{Co}^{2+}, \mathrm{Ni}^{2+}, \mathrm{Pb}^{2+}, \mathrm{CrO}_{4}^{2-}, \mathrm{VO}_{3}^{-}, \mathrm{CrO}_{4}{ }_{4}^{2-}, \mathrm{MoO}_{4}{ }^{2-}\right)$. They are accumulated (absorbed) by microorganisms due to the stereochemical analogy of macroelements necessary for metabolism $\left(\mathrm{K}^{+}, \mathrm{Na}^{+}, \mathrm{Ca}^{2+}, \mathrm{Mg}^{2+}, \mathrm{NH}_{4}^{+}\right.$,
$\mathrm{SO}_{4}{ }^{2-}, \mathrm{PO}_{4}{ }^{3-}$ ) [68]. Stereochemical analogy implies the proximity or equality of the ionic radii of macroelements and metals (Fig. 5). All metals of the periodic system of elements have stereochemical analogs. Acceptor transport systems are mistaken and absorb toxic metals along with macroelements.

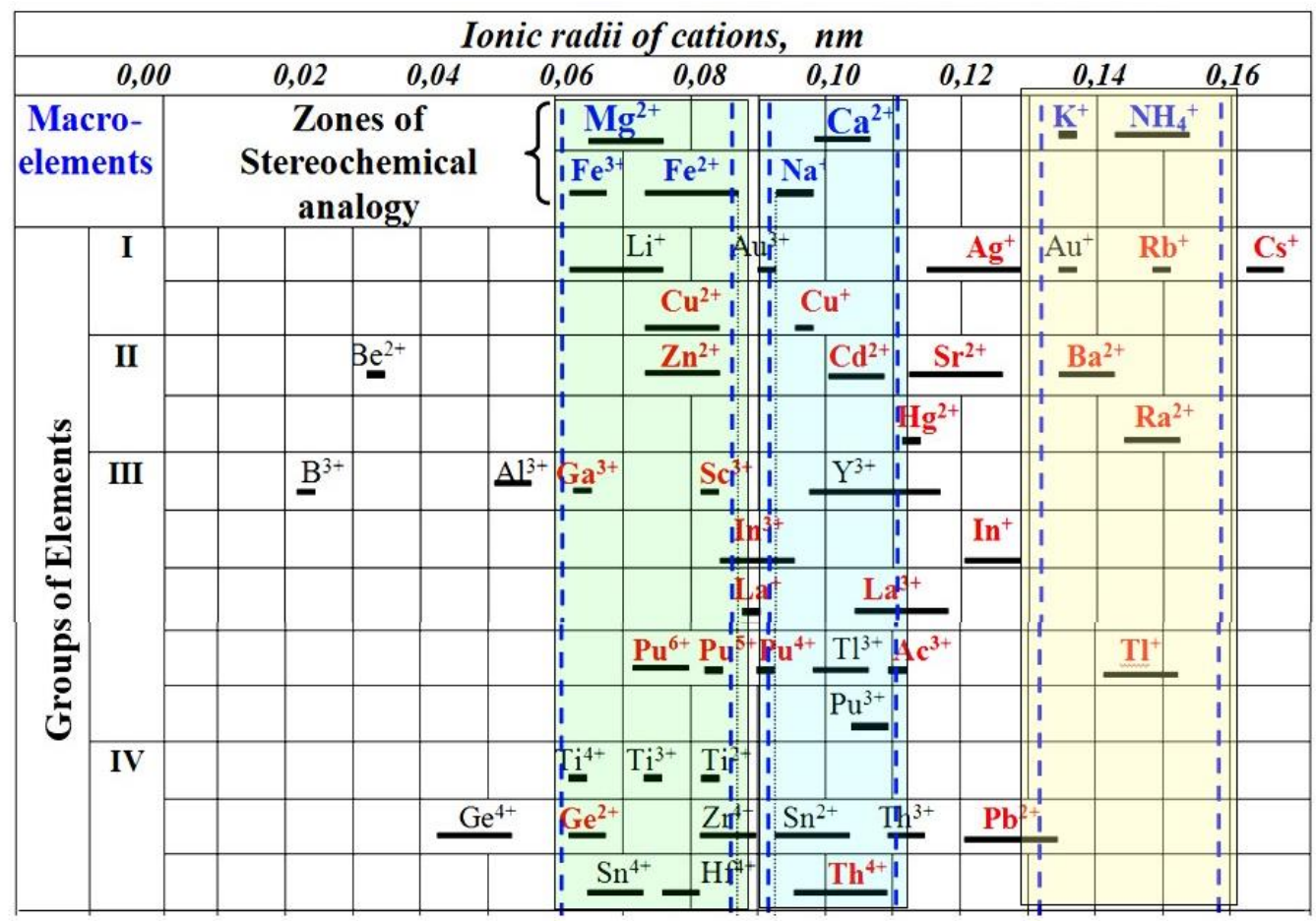

Fig. 5. Stereochemical analogy of macroelements and toxic metals 
Thermodynamically grounded non-specificity of interaction of microorganisms with metals suggests that microbial communities can simultaneously interact with a wide range of metals (removal from solution) both by mechanisms of redox-transformation, and stereochemical analogy [69]. It is necessary to note a very important consequence of the thermodynamic prediction. There are no theoretical limitations on the growth and interaction of microorganisms with metals at their arbitrarily high concentrations (up to singlemolar) [71]. This provision was confirmed experimentally by the example of such toxic metals as $\mathrm{Hg}^{2+}, \mathrm{CrO}_{4}{ }^{2-}$ and $\mathrm{Cu}^{2+}[72]$.

The experimental confirmation on the example of chromate anion and $\mathrm{Hg}$ (II) cation is very indicative. Chromate belongs to the most powerful oxidizing metals and causes the death of microorganisms even at a concentration of 50-100 $\mathrm{mg} / \mathrm{l}[43 ; 80]$. Strains capable of surviving at such concentrations of chromate and reducing it to insoluble $\mathrm{Cr}$ (III) hydroxide are considered highly stable and promising for industrial biotechnologies $[10 ; 48,76]$.

However, we showed the possibility of growth and reduction of $\mathrm{Cr}(\mathrm{VI})$ to insoluble $\mathrm{Cr}(\mathrm{OH})_{3} \cdot \mathrm{nH}_{2} \mathrm{O}$ even in the concentration range $30000-60000 \mathrm{ppm}$ of $\mathrm{Cr}(\mathrm{VI})$. The possibility of growth of microbial community at $1000 \mathrm{ppm}^{2+}{ }^{2+}$ is particularly indicative. Moreover, microorganisms not only grew at the indicated mercury concentration, but also completely removed it from the solution within 3 days [73]. For comparison, we point out that microorganisms growing in the presence of $5 \mathrm{ppm}$ of mercury are stable, and at $10 \mathrm{ppm}$ are extremely resistant to such mercury concentrations $[5,9,29,58,77]$. It should be noted that mercury refers to metals of so-called combined action, i.e. simultaneously it is a strong oxidizing metal and a substitutor. Thus, the standard potential of the $\mathrm{Hg}^{2+}$ reduction reaction to $\mathrm{Hg}^{0}$ is $+760 \mathrm{mV}(+789 \mathrm{mV}$; $\mathrm{pH}=2,0)[50,67]$. At the same time, $\mathrm{Hg}^{2+}$ cation is stereochemical analog to $\mathrm{Ca}^{2+}[68]$. Hence, it can be assumed that microbial communities of natural ecosystems simultaneously carry out accumulation of $\mathrm{Hg}^{2}+$ due to its reduction to insoluble $\mathrm{Hg}(\mathrm{I})$ or $\mathrm{Hg}^{0}$, and due to transport into cells simultaneously with $\mathrm{Ca}^{2+}$ (Fig. 5).

Purification of copper-containing sewage can also be carried out by microorganisms resistant to high concentrations of copper and capable of decreasing the concentration of copper in wastewater. Akponah showed uptake of copper by Bacillus strains. At initial metal concentration of $1.0 \mathrm{ppm}$ the values of uptake ranges were $7.40-12.00(\mathrm{mg} / \mathrm{g}$ dry $\mathrm{wt})$ [2].
We showed growth at high concentrations of copper and its uptake by the culture of yeast Candida tropicalis RomCu5. The culture was able to grow at concentration of $\mathrm{Cu}^{2+} 30000 \mathrm{ppm}$ in citrate form and at $500 \mathrm{ppm}$ of $\mathrm{Cu}^{2+}$ in $\mathrm{CuCl}_{2}$ form. The culture was not only resistant, but interacted with copper despite the inhibitory action of copper at such high concentrations. C. tropicalis reduced the concentration of copper in the form of copper citrate by $15 \%$, that is, from 100 to $85 \mathrm{ppm}$. It was also shown that the strain accumulated copper better in the form of copper chloride. The concentration of copper in the solution decreased by $45 \%$, namely from 100 to $55 \mathrm{ppm}$ [52].

Also microorganisms of the granulated microbial preparation developed by us are of special practical interest for purification of metal-containing wastewater. These microorganisms grow and interact with $\mathrm{Cu}$ (II) at a concentration of $10000 \mathrm{ppm}$ $\mathrm{Cu}^{2+}[72]$.

\section{Purification of liquid radioactive waste (LRW)}

From the point of view of chemistry, the peculiarity of radionuclides in LRW is their extremely small or even vanishingly small concentration of chemical elements with their high radioactivity. As is known, that removal of metals in vanishingly small concentrations is a difficultly solvable or generally unsolved problem. It follows that to increase the efficiency of extraction of vanishingly small amounts of radionuclides, it is necessary to integrate at least three thermodynamically admissible types of interaction of microorganisms with radionuclides. These include:

1. Reduction to insoluble compounds [37]:

$$
\begin{aligned}
& { }^{51} \mathrm{CrO}_{4}{ }^{2-}+(\mathrm{n}-1) \mathrm{H}_{2} \mathrm{O}+5 \mathrm{H}^{+}+3 \mathrm{e}={ }^{51} \mathrm{Cr}(\mathrm{OH})_{3} \cdot \mathrm{nH}_{2} \mathrm{O} \downarrow \\
& { }^{235} \mathrm{UO}_{2}{ }^{2+}+2 \mathrm{e} \rightarrow{ }^{235} \mathrm{UO}_{2} \downarrow \text { etc. }
\end{aligned}
$$

2. Cellular accumulation of radionuclides as stereochemical analogues of macroelements $\left({ }^{90} \mathrm{Sr}^{2+}\right.$ and $\mathrm{Ca}^{2+},{ }^{51} \mathrm{CrO}_{4}{ }^{2-}$ and $\mathrm{SO}_{4}{ }^{2-}$ etc.) [20].

3. Formation of insoluble compounds with microbial exometabolites $\left({ }^{90} \mathrm{SrS},{ }^{60} \mathrm{CoS},{ }^{194} \mathrm{HgS}\right.$ etc.) $[7,41]$.

It is also obvious that efficiency of extraction of radionuclides is proportional to the concentration of microorganisms. Sorption of microorganisms on inert carriers is used to increase their concentration. However, it must be taken into account that at an arbitrarily high concentration of biomass only 2-5\% are microorganisms, and $95-98 \%$ is water. Hence, it is obvious that traditional methods of biomass concentration to improve the efficiency of radionuclide extraction can not have a positive 
effect $[13,22]$. The granulated microbial pellets were developed to maximize the concentration of microorganisms. Microbial pellets consist of 90-95\% of living microbial cells [74]. A feature of microbial pellets is its stability in aqueous solutions. The high concentration of microorganisms and integration of mechanisms for extracting of radionuclides through the use of diversified microbial communities made it possible to achieve highly efficient LRW treatment, a decrease in their activity by 3-6 orders [75] (Table 1):

Table 1. Efficiency of extraction of radionuclides by microbial pellets

\begin{tabular}{|c|c|c|c|c|}
\hline \multirow{2}{*}{$\mathrm{RN}$} & \multicolumn{3}{|c|}{ Activity of radionuclides, Ki / kg } & \multirow{2}{*}{$\begin{array}{c}\text { The order of } \\
\text { LRW activity } \\
\text { reduction }\end{array}$} \\
\cline { 2 - 4 } & Initial in LRW & $\begin{array}{c}\text { In Microbial } \\
\text { pellets }\end{array}$ & $\begin{array}{c}\text { In LRW after } \\
\text { purification }\end{array}$ & 6 \\
\hline${ }^{51} \mathrm{Cr}$ & $3,90 \cdot 10^{-7}$ & $1,18 \cdot 10^{-8}$ & - & 5 \\
\hline${ }^{54} \mathrm{Mn}$ & $6,70 \cdot 10^{-8}$ & $4,72 \cdot 10^{-8}$ & - & 5 \\
\hline${ }^{60} \mathrm{Co}$ & $1,09 \cdot 10^{-6}$ & $5,3 \cdot 10^{-7}$ & $5,36 \cdot 10^{-11}$ & 6 \\
\hline${ }^{83} \mathrm{Rb}$ & $6,22 \cdot 10^{-7}$ & $4,16 \cdot 10^{-7}$ & - & 6 \\
\hline${ }^{90} \mathrm{Sr}$ & $3,52 \cdot 10^{-7}$ & $3,39 \cdot 10^{-7}$ & - & 4 \\
\hline${ }^{137} \mathrm{Cs}$ & $1,36 \cdot 10^{-5}$ & $7,81 \cdot 10^{-6}$ & $3,36 \cdot 10^{-9}$ & 5 \\
\hline${ }^{140} \mathrm{La}$ & $7,01 \cdot 10^{-8}$ & $9,67 \cdot 10^{-9}$ & - & 3 \\
\hline${ }^{144} \mathrm{Ce}$ & $6,17 \cdot 10^{-6}$ & $3,50 \cdot 10^{-8}$ & $7,22 \cdot 10^{-9}$ & 2 \\
\hline${ }^{226} \mathrm{Ra}$ & $1,21 \cdot 10^{-6}$ & $1.11 \cdot 10^{-6}$ & $7,60 \cdot 10^{-8}$ & 6 \\
\hline
\end{tabular}

Also, we obtained very high rates of extraction of uranium and transuranic elements from aqueous solutions using microbial pellets (Table 2) [70]. It should be noted that the extraction efficiency of radionuclides was high $\left(R^{l}=98.9-99.1 \%\right)$ even with a small weight ratio of pellets and LRW (1:100). An even greater increase in efficiency (up to 99.8\%) was obtained by increasing the amount of pellets (up to a ratio of 1:20). It should also be noted that the efficiency in the form of $K d^{2}$ was very high at a phase ratio of 1:100. Thus, for the ${ }^{238} \mathrm{U}, \mathrm{Kd}=9400 \pm 500$, and for ${ }^{239} \mathrm{Pu}$ and ${ }^{241} \mathrm{Am}$, respectively, $11000 \pm 600$ and $11400 \pm 600$.

Francis and Nancharaiah [20] analyzed numerous studies and discovered that the uranium present in the natural ecosystems can be reduced by the indigenous

${ }^{1} R=\left(\Delta C: C_{o}\right) \times 100 \%$ - degree of metals recoveryduction

${ }^{2} \boldsymbol{K d}=\left(\Delta \boldsymbol{C}: \boldsymbol{C}_{\boldsymbol{o}}\right) \times\left(\boldsymbol{m}_{1}: \boldsymbol{m}_{2}\right)-$ coefficient of metals accumulation, where; $\boldsymbol{C}_{\boldsymbol{o}}$ - initial concentration of radionuclide (metal) in solution; $\Delta \boldsymbol{C}$ - the difference between the initial $(\boldsymbol{C o})$ and final $(\boldsymbol{C p})$ concentrations of the radionuclide (metal) in the solution; $\boldsymbol{C}_{\boldsymbol{p}}$ - equilibrium or final concentration of radionuclide (metal) in solution; $\boldsymbol{m}_{\boldsymbol{l}}-$ solution weight; $\boldsymbol{m}_{2}$ - absolutely dry weight of microorganisms. microorganisms of the contaminated zones, but to stimulate this process they need additional electron donors such as acetate, ethanol, or lactate.

At the same time, Hu et al showed uptake of 2.13 mg U/g (dry weight) by P. aeruginosa CSU [31].

Das made comparison and revealed that Pseudomonas aeruginosa CSU showed more biosorption potential towards uranium(VI) comparing to algal and fungal biosorbents [13].

Regarding microbial reduction of $\mathrm{Pu}(\mathrm{IV})$ to $\mathrm{Pu}(\mathrm{III})$, Jonathan R. Lloyd showed [37] that it can be achieved by $\mathrm{Fe}$ (III)-reducing bacteria. However, until now the biochemical basis of these transformations remains uncharacterised. 
Table 2. Accumulation of ${ }^{238} \mathrm{U},{ }^{239} \mathrm{Pu}$ and ${ }^{241} \mathrm{Am}$ using microbial pellets

\begin{tabular}{|c|c|c|c|c|}
\hline \multirow[t]{2}{*}{ № } & \multirow[t]{2}{*}{$\begin{array}{l}\text { Radionuclide } \\
\qquad C_{0}, \mathrm{Bk} / \mathrm{kg}\end{array}$} & \multicolumn{3}{|c|}{$\begin{array}{l}\text { Indicators of accumulation of } \\
\text { radionuclides by microbial pellets (during } \\
5 \text { days) }\end{array}$} \\
\hline & & $C_{p}, \mathrm{Bk} / \mathrm{kg}$ & $R, \%$ & $K d$ \\
\hline
\end{tabular}

Weight ratio of "pellets: solution" 1:100

\begin{tabular}{|c|c|c|c|c|}
\hline 1 & ${ }^{238} \mathrm{U} 520 \pm 10$ & $5,5 \pm 0,1$ & 98,9 & $9400 \pm 500$ \\
\hline 2 & ${ }^{239} \mathrm{Pu} 1600 \pm 40$ & $14,4 \pm 0,1$ & 99,1 & $11000 \pm 600$ \\
\hline 3 & ${ }^{241} \mathrm{Am} 200 \pm 80$ & $27,8 \pm 0,7$ & 99,1 & $11400 \pm 600$ \\
\hline
\end{tabular}

Weight ratio of "pellets: solution" 1:20

\begin{tabular}{|c|c|c|c|c|}
\hline 4 & ${ }^{238} \mathrm{U} 520 \pm 10$ & $0,99 \pm 0,03$ & 99,8 & $10500 \pm 500$ \\
\hline 5 & ${ }^{239} \mathrm{Pu} 1600 \pm 40$ & $2,50 \pm 0,06$ & 99,8 & $12800 \pm 600$ \\
\hline 6 & ${ }^{241} \mathrm{Am} 3200 \pm 80$ & $5,2 \pm 0,1$ & 99,8 & $12300 \pm 600$ \\
\hline
\end{tabular}

Development of combined waste treatment biotechnology

The fundamental novelty of our thermodynamic approach is that we can theoretically justify and practically implement novel efficient and costeffective biotechnologies. On the base of theoretical calculations, it is possible to detoxify several types of toxic compounds and simultaneously obtain a number of valuable products in one biotechnology. For example, destruction of MFW by its hydrogen fermentation, simultaneous detoxification of chromatecontaining wastewater from galvanic industries is possible. Hydrolysis MFW under anaerobic conditions leads to decrease of redox potential to $-250 \mathrm{mV}$ :

$$
\left[\mathrm{C}_{6} \mathrm{H}_{12} \mathrm{O}_{6}\right]_{\mathrm{n}} \rightarrow \mathrm{nC}_{6} \mathrm{H}_{12} \mathrm{O}_{6} \ldots \rightarrow \mathrm{C}_{6} \mathrm{H}_{12} \mathrm{O}_{6} \rightarrow 6 \mathrm{H}_{2}+6 \mathrm{CO}_{2} \quad \text { Eh }=-250 \mathrm{MB} .
$$

The redox-potential of the reaction of reduction of chromate anion to insoluble (and therefore non-toxic) chromium(III) hydroxide is $+555 \mathrm{mV}$ :

$$
\mathrm{CrO}_{4}{ }^{2-}+(\mathrm{n}-1) \mathrm{H}_{2} \mathrm{O}+5 \mathrm{H}^{+}+3 \mathrm{e}=\mathrm{Cr}(\mathrm{OH})_{3} \cdot \mathrm{nH}_{2} \mathrm{O} \downarrow \quad \mathrm{Eh}=+555 \mathrm{MB} .
$$

When chromate is added to the metabolically active culture of hydrogen producers, a potential difference between donor and acceptor systems is $805 \mathrm{mV}$. Hence, simultaneously the following processes will occur: destruction of MFW, synthesis

of hydrogen and toxic chromate anion removal by its reduction to insoluble chromium(III) hydroxide. The above theoretical justification is confirmed experimentally (Fig. 6) [59].

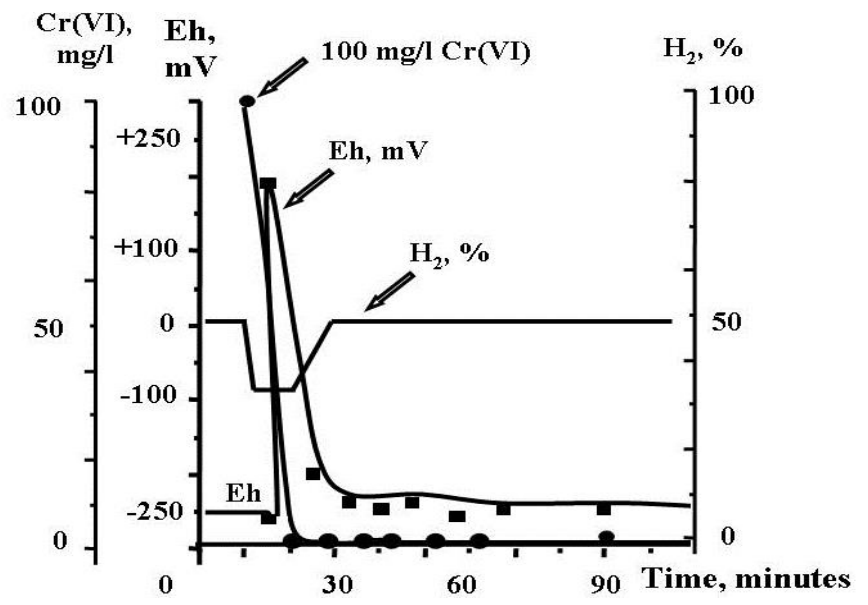

Fig. 6. High efficiency of combined waste treatment biotechnology 
Under the active phase of hydrogen fermentation, the redox potential was $-250 \mathrm{mV}$. When chromium(VI) was added at a concentration of $100 \mathrm{ppm}$, a sharp increase in the redox potential to $+200 \mathrm{mV}$ was observed. Naturally, due to significant difference of potentials between donor and acceptor systems, a very rapid reduction of chromate anion occurred. Its concentration decreased to an analytical zero (i.e., less than $0.1 \mathrm{ppm}$ ) during $10 \mathrm{~min}$. Addition of chromate led to impermanent inhibition of hydrogen synthesis, which was completely restored within 20 minutes. It should be emphasized that so-called industrial strains of chromate reducing microorganisms reduce $\mathrm{CrO}_{4}{ }^{2-}$ in a concentration of $100 \mathrm{ppm}$ during 12-24 hours. In our experiment, the complete reduction of chromate at this concentration occurs during 20 minutes. As a result, the following positive effects were obtained: simultaneous destruction of environmentally hazardous MFW and toxic metal removal from the solution as well as synthesis of environmentally friendly energy carrier - hydrogen and obtaining of chromium concentrate. We gave just one example of combining several biotechnologies. Similar effective biotechnologies can also be developed for other options, for example, simultaneous detoxification of toxic food waste filtrate and removal of a wide range of metals from industrial wastewater from mining enterprises.

\section{CONCLUSIONS}

The thermodynamic prognosis allows finding effective ways of solving environmental problems that do not have a solution now. It is a promising method for development of universal effective biotechnologies for treatment of a wide range of hazardous wastes: food (solid and liquid), metals and radionuclides. The theoretical bases of environmental biotechnologies developed by us are promising for their industrial implementation to prevent and stop environment pollution by all four types of hazardous waste as well as for bioremediation of contaminated ecosystems.

\section{REFERENCES}

1. Ababouch L., A. Chaibi, F. F. Busta, Inhibition of Bacterial Spore Growth by Fatty Acids and Their Sodium Salts. J. Food Prot., Vol. 5, No. 12, 1992, 980-984.

2. Akponah E., Bacterial and fungal biosorbents of heavy metals associated with hydrocarbon contaminated rainforest soils of the Niger delta region of Nigeria, Eur. J. Exp. Biol., Vol. 3, No. 3, 2013, 95-100.
3. Alvarez-Ayuso E., A. García-Sánchez, X. Querol, Purification of Metal Electroplating Waste Waters Using Zeolites, Water Res., Vol. 37, No. 20, 2003, 4855-62.

4. Angenent L. T., K. Karim, M.H. Al-Dahhan, B. A. Wrenn, R.Domiguez-Espinosa, Production of bioenergy and biochemicals from industrial and agricultural wastewater, Trends Biotechnol., Vol. 22, No. 9, 2004, 477-485.

5. Babich H., G., Stotzky Differential toxicities of mercury to bacteria and bacteriophages in sea and in lake water, Can. J. Microbiol., Vol. 25, No.11, $1979,1252-1257$.

6. Bambang V., K. Jae-Duck, Supercritical water oxidation for the destruction of toxic organic wastewaters: A review, J. Environ. Sci., Vol. 19, 2007, 513-522.

7. Barkay T., J. Schaefer, Metal and radionuclide bioremediation: issues, considerations and potentials, Curr. Opin. Microbiol., Vol. 4, 2001, 318-323.

8. Boyd S. A., M. M. Mortland, G. T. Chiou, Sorption Characteristics of Organic Compounds on Hexadecyltrimethylammonium-Smectite, SSSA Journal, Vol. 52, 1988, 652-657.

9. Brown T.A., D.G. Smith, Cytochemical localization of mercury in Cryptococcus albidus grown in the presence of mercuric chloride, J. Gen. Microbiol., Vol. 99, No. 2, 1977, 435-439.

10. Cheung K.H., Ji-DongGu, Mechanism of hexavalent chromium detoxification by microorganisms and bioremediation application potential: A review, Int. Biodeter. Biodegr., Vol. 59, No.1, 2007, 8-15.

11. Daniel D. E., Waste Disposal and Underground, Storage in Ground Engineer's Reference Book, F. G. Bell (ed.), Butterworths, London, 1987, 43/1-43/10 pp.

12. Daniel D. E. (Ed.) Geotechnical Practice for Waste Disposal, Chapman and Hall, London, 1993, $683 \mathrm{p}$.

13. Das N., Remediation of Radionuclide Pollutants through Biosorption - an Overview, Clean Soil Air Water, Vol. 40, 2012, 16-23.

14. De Clercq D., Z. Wen, F. Fan, L. Caicedo, Biomethan production potential from restaurant food waste in megacities and project level-bottlenecks: A case study in Beijing, Renew. Sust. Energ. Rev., Vol. 59, 2016, 1676-1685.

15. Devindra S., T. Longvah, Analysis of Digestible Carbohydrates in Different Varieties of Basmati Rice and Other Popular Cereal Samples by Using HPLC-RI, World J. Dairy Food Sci., Vol. 6, No. 2, 2011, 146-151.

16. Duruibe, J. O., M. O. C Ogwuegbu, J. N. Egwurugwu, Heavy metal pollution and human 
biotoxic effects, Int. J. Phys. Sci., Vol. 2, No. 5, 2007, 112-118.

17. Fang H.H.P., C.L. Li, T. Zhang, Acidophilic biohydrogen production from rice slurry. Int. J. Hydrogen Energ,, Vol. 31, 2006, 683-692.

18. Feng, X., Z.Wu, X. Chen, Removal of metal ions from electroplating effluent by EDI process and recycle of purified water, Sep. Purif. Technol., Vol. 57, 2007, 257-263.

19. Fischera H. W., Y. Yokoo, Preliminary Comparison of Radioisotope Concentration in Sewage Sludge after the Fukushima and Chernobyl Accidents, Energy Procedia, Vol. 59, 2014, 256 - 262.

20. Francis A.J; Y.V. Nancharaiah, In situ and ex situ bioremediation of radionuclide-contaminated soils at nuclear and NORM sites, Environmental Remediation and Restoration of Contaminated Nuclear and NORM Sites, Vol. 9, 2015, 85-236.

21. Fu F., Q. Wang, Removal of heavy metal ions from wastewaters: A review, J. Environ. Manage., Vol. 92, 2011, 407-418.

22. Gadd G. M., Biosorption: critical review of scientific rationale, environmental importance and significance for pollution treatment. J Chem Technol Biotechnol, Vol. 84, 2009, 13-28.

23. Grimm N. B., S. H. Faeth, N. E. Golubiewski, C. L.Redman, J. Wu, X. Bai, J. M. Briggs, Global Change and the Ecology of Cities, Science, Vol. 319, 2008, 756-760.

24. Gunatilake S.K., Methods of Removing Heavy Metals from Industrial Wastewater, JMESS, Vol. 1, No.1, 2015, 12-18.

25. Guzel-Seydim Z. B., A.K. Greene, A.C. Seydim, Use of ozone in the food industry, Lebensmittel-Wissenschaft und -Technologie, Vol. 37, 2004, 453-460.

26. Hagare D., M. Sivakumar, R. N. Singh, Wastewater characteristics, management and reuse in mining and mineral processing industries. In S. Vigneswaran (Ed.), Wastewater Recycle, Reuse, and Reclamation. Vol. 1, 2009, 337-371 pp.

27. Han S.K., H.S. Shin, Enhanced acidogenic fermentation of food waste in a continuous-flow reactor, Waste Manag. Res., Vol. 20, 2002, 110-118.

28. Han S.K., H.S. Shin, Two Stage Process Converting Food Waste to Hydrogen and Methane, J. Air Waste Manage., Vol. 54, No, 2, 2004, 242249.

29. Horitsu H., M.Takagi, M. Tomoyeda, Isolation of a mercuric chloride-tolerant bacterium and uptake of mercury by the bacterium, Eur. J. Appl. Microbiology and Biotechnology, Vol. 5, No. 4, 1978, 279-290.

30. Hudson-Edwards K. A., H. E. Jamieson, B. G. Lottermoser, Mine Wastes: Past, Present, Future. Elements, Vol. 7, No. 6, 2011, 375-380.
31. Hu M. Z. C., J. M. Norman, B. D. Faison, M. E. Reeves, Biosorption of Uranium by Pseudomonas aeruginosa Strain CSU: Characterization and Comparison Studies, Biotechnol. Bioeng., Vol. 51, No. 2, 2000, 237.

32. Khalid A., M. Arshad, M. Anjuma, T. Mahmood, L. Dawson, The anaerobic digestion of solid organic waste, Waste Manage., Vol. 31, 2011, 1737-1744.

33. Kim S.H., H.S. Shin, Effects of basepretreatment on continuous enriched culture for hydrogen production from food waste, Int. J. Hydrogen Energ., Vol. 33, No. 19, 2008, 5266-5274.

34. Kobya M., E. Demirbas, N.U. Parlak, S. Yigit, Treatment of cadmium and nickel electroplating rinse water by electrocoagulation, Environ Technol. J., Vol. 31, No. 13, 2010, 1471-1481.

35. Koster I. W., A. Cramer, Inhibition of Methanogenesis from Acetate in Granular Sludge by Long-Chain Fatty Acids, Appl. Environ. Microbiol., Vol. 53, No. 2, 1987, 403-409.

36. Lee Z.K., S.L. Li, P.C. Kuo, I. C. Chen, Y.M. Tien, Y.J. Huang, C.P. Chuang, S.C. Wong, S.S. Cheng, Thermophilic bio-energy process study on hydrogen fermentation with vegetable kitchen waste, Int. J. Hydrogen Energ., Vol. 35, 2010, 13458-13466.

37. Lloyd J. R., Microbial reduction of metals and radionuclides, FEMS Microbiol. Rev., Vol. 27, No. 2-3, 2003, 411-425.

38. Malaták J., T. Dlabaja, Hydrothermal carbonization of kitchen waste. J. Agr. Eng. Res., Vol. 62, 2016, 64-72.

39. Marder L., A. M. Bernardes, J. Z. Ferreira, Cadmium Electroplating Wastewater Treatment Using a Laboratory Scale Electrodialysis System, Sep. Purif. Technol., Vol. 37, No. 3, 2004, 247-255.

40. Martín-Lara M.A., G. Blázquez, M.C. Trujillo, A. Pérez, M. Calero, New treatment of real electroplating wastewater containing heavy metal ions by adsorption onto olive stone, J. Clean. Prod., Vol. 81, 2014, 120-129.

41. Martinez R. J., M. J. Beazley, M. Taillefert, A. K.Arakaki, J. Skolnick, P. A. Sobecky, Aerobic uranium (VI) bioprecipitation by metal- resistant bacteria isolated from radionuclide- and metal- contaminated subsurface soils, Environ. Microb., Vol. 9, 2007, 3122-3133.

42. Mazumder D., D. Ghosh, P. Bandyopadhyay, Treatment of Electroplating Wastewater by Adsorption Technique, IJCEE, Vol. 3, No. 2, 2011, 101-110.

43. Nriagu J.O., E. Nieboer, Chromium in the Natural and Human Environments, John Wiley \& Sons, 1988, 571.

44. Orescanin V., R. Kollar, I. L.Mikelic, K. Nad, Electroplating wastewater treatment by the 
combined electrochemical and ozonation methods, J. Environ. Sci. Heal., Part A, Vol. 48, No. 11, 2013, 1450-1455.

45. Palaniswamy R, C. Veluchamy, Biosorption of Heavy Metals by Spirulina platensis from Electroplating Industrial Effluent, Indian J. Environ. Sci., Vol. 13, No. 4, 2017, 139.

46. Panayotova T., M. Dimova-Todorova, I. Dobrevsky, Purification and reuse of heavy metals containing wastewaters from electroplating plants, Desalination, Vol. 206, No. 1-3, 2007, 135-140.

47. Pandian K., A. J. Thatheyus, D. Ramya, Bioremoval of Chromium, Nickel And Zinc in Electroplating Effluent by Pseudomonas aeruginosa, Open J. of Wat. Poll. Treat., Vol.1, No. 2, 2014, 2374-6343.

48. Pepi F.S. M. Focardi, Microbial reduction of hexavalent chromium as a mechanism of detoxification and possible bioremediation applications, Chamy R (ed), Biodegradation life of science, 2013, 321-348.

49. Pham T. P. T., R. Kaushik, G. K. Parshetti, R. Mahmood, Food waste-to-energy conversion technologies: Current status and future directions, Waste Manage., Vol. 38, 2015, 399-408.

50. Pourbaix, M., Atlas of electrochemical equilibria in aqueous solutions (English edition), Pergamon press, Oxford, 1963, $320 \mathrm{p}$.

51. Prabhu S. V., R. Baskar, Detoxification of Electroplating Sludge by Bioleaching: Process and Kinetic Aspects, Pol. J. Environ. Stud., Vol. 24, No. 3, 2015, 1249-1257.

52. Prekrasna E. P., O. B. Tashyrev, Copper resistant strain Candida tropicalis Romcu5 interaction with soluble and insoluble copper compounds, Biotechnol. Acta, Vol. 8, No. 5, 2015, 93-102.

53. Reungsanga A., C. Sreela-orc, P. Plangklanga, Non-sterile bio-hydrogen fermentation from food waste in a continuous stirred tank reactor (CSTR): Performance and population analysis, Int $\mathrm{J}$ Hydrogen Energ, Vol. 38, 2013, 15630-15637.

54. Sannigrahi A. K., Major Constraints in Popularising Vermicompost Technology in Eastern India., 2016, Modern Environ. Sci. and Engin., Vol. 2, No. 2, 123-133.

55. Semmens M. J., C.D. Dillon, C. Riley, An evaluation of continuous electro deionization as an in-line process for plating rinse water recovery, Environmental Progress, Vol. 20, 2001, 251-260.

56. Sharholy M., K. Ahmad, G. Mahmood, R.C. Trivedi, Municipal solid waste management in Indian cities - A review, Waste Management, Vol. 28, No. 2008, 459-467.

57. Shibata T., H. Solo-Gabriele, T. Hata, Disaster waste characteristics and radiation distribution as a result of the Great East Japan Earthquake, Environ Sci. Technol., Vol. 46, 2012, 3618-3624.

58. Shiratori T., Ch. Inone, K. Sugawara, T. Kusano, Yo. Kitagowa, Cloning and expression of Thiobacillus ferrooxidans mercury ion resistance genes in Escherichia coli, J. Bacteriol., Vol. 171, No. 6, 1989, 3458-3464.

59. Sioma I.B., A.B. Tashyrev, V.M. Govorukha, Y.P. Prekrasna, Toxic metals extraction during potato fermentation, Ecolog. Engin. Environ. Prot., Vol. 8, 2017, 62-67.

60. Suslova O., V. Govorukha, O. Brovarskaya, N. Matveeva, H. Tashyreva, O. Tashyrev, Method for Determining Organic Compound Concentration in Biological Systems by Permanganate Redox Titration, Int. J. Bioautomation, Vol. 18, No. 1, 2014, 45-52.

61. Sze K.F., Y.J. Lu, P.K. Wong, Removal and recovery of copper ion $\left(\mathrm{Cu}^{2+}\right)$ from electroplating effluent by a bioreactor containing magnetiteimmobilized cells of Pseudomonas putida 5X, Resour. Conserv. Recy., Vol. 18, No. 1-4, 1996, 175-193.

62. Tang X., H. Zheng, H. Teng, Y. Sun, J. Guo, W. Xie, Q.Yang, W. Chen, Chemical coagulation process for the removal of heavy metals from water: a review, Desalination Water Treat., Vol. 57, No. 4, 2014, 1733-1748.

63. Tashyreva H., O. Tashyrev, V. Govorukha, O. Havryliuk, The effect of mixing modes on biohydrogen yield and spatial ph gradient at dark fermentation of solid food waste, Ecolog. Engin. Environ. Prot., Vol. 2, 2017, 53-62.

64. Tashyrev O.B., N.A. Matvieieva, P.V. Rokitko, Development of novel universal industrial biotechnology for the processing and disposal of environmentally hazardous food waste at Antarctic stations, IV International Antarctic Conference, Kyiv, Ukraine, May 12-14, 2009, 179 p.

65. Tashyrev O. B., Biotechnologies of industrial waste water purification on the basis of thermodynamic prediction of the interaction of microorganisms with metals and radionuclides: author's abstract dis d. tehn. Sciences, 03.00.20, Oleksandr Borysovich Tashyrev, NUKHT, Kyiv, 2005, 33 p.

66. Tashyrev O.B., Application of microbial biocatalytic technology for treatment of chromate containing sewage, Food Industry, Vol. 4, 2005, 70-73.

67. Tashyrev O.B., Theoretical aspects of the interaction of microorganisms with metals. Restorative transformation of metals, Microbiol. J., Vol. 56, No. 6, 1994, 76-88.

68. Tashyrev O.B., Theoretical aspects of the interaction of microorganisms with metals. Microbial accumulation of metals, due to their stereochemical 
analogy with macroelements, Microbiol. J., Vol. 56, No. 6, 1994, 89-100.

69. Tashyrev O.B., The concept of integral mechanisms of metal accumulation by syntrophic microbial community, Microbiol. J., Vol. 61, No. 5, 1999, 78-84.

70. Tashyrev O.B., Accumulation of uranium, plutonium and americium with a microbial biosorbent, Microbiol. J., Vol. 62, No. 6, 2000, 51-56.

71. Tashyrev O.B, E.V. Galinker, E.I. Andreyuk, Thermodynamic prediction of the redox interaction of microorganisms with oxidizing metals $\left(\mathrm{Hg}^{2+}\right.$, $\mathrm{CrO}_{4}^{2-}$ and $\left.\mathrm{Cu}^{2+}\right)$, Reports of the National Academy of Sciences of Ukraine, Vol. 4, 2008, 160-172.

72. Tashyrev O.B., N.A. Matveeva, A.A. Tashyreva, V.O. Romanovskaya, Experimental substantiation of thermodynamic prediction of redox interaction of microorganisms with oxidizing metals $\left(\mathrm{Hg}^{2+}, \mathrm{CrO}_{4}{ }^{2-}\right.$ and $\left.\mathrm{Cu}^{2+}\right)$, Reports of the National Academy of Sciences of Ukraine, Vol. 5, 2008, 174180.

73. Tashyrev O.B., N.A. Matveeva, V.O. Romanovskaya, A.O. Tashyreva, P.V. Rokytko, Multidrug resistance and superstability to heavy metals of Antarctic microorganisms, Reports of the National Academy of Sciences of Ukraine, Vol. 11, 2007, 170-175.

74. Tashyrev O.B, V.M. Shevel, 1999, Method of purification of aqueous solutions from metal ions by biomass of microorganisms, Pat. 10809 UA, МПК5 CO2 F 1/28, 3/34; G21 F9 / 18. / Published Feb. 26, 1999, Bul. №1.

75. Tashyrev O.B, V.N. Shevel, Accumulation of a wide spectrum of radionuclides by a granular microbial biocatalyst. In: Problems of Chornobyl, Materials of the IV International Scientific and Practical Conference "Object" Shelter ". 15 years: past, present, future." Chernobyl, Ukraine, 27-30 November 2002, 1(10), 2002, 336-343 pp.

\section{Principal investigator Prof. Oleksandr Tashyrev \\ Head of the Department Zabolotny \\ Zabolotny Institute of Microbiology and Virology of the NAS of Ukraine, Department of Extremophilic Microorganism Biology 154, Zabolotny str., Kiev, 03143, Ukraine tel.: +380445263297 \\ e-mail: tach2007@ukr.net}

\section{Researcher Valery Shevel}

Institute for Nuclear Research of the NAS of Ukraine Department of the Research Nuclear Reactor b.47, Prospekt Nauky, Kiev, 03680, Ukraine tel.: +380445257289

e-mail: Shevel@nas.gov.ua
76. Thatheyus A. J., D. Ramya Biosorption of Chromium Using Bacteria: An Overview, Sci. International, Vol. 4, 2016, 74-79.

77. Trevors J.T., Mercury methylation by bacteria, J. Bas. Microbiol., Vol. 26, No. 8, 1986, 499-504.

78. Wang J., C. Chen, Biosorbents for heavy metals removal and their future, Biotechnol. Advances, Vol. 27, 2009, 195-226.

79. Wang X., Y. A. Zhao, A bench scale study of fermentative hydrogen and methane production from food waste in integrated two-stage process, Int. J. Hydrog. Energy, Vol. 34, No. 1, 2009, 245-254.

80. Ware G., Reviews of Environmental Contamination and Toxicology: Continuation of Residue Reviews, Springer Science and Business Media, 2006, 168.

81. Wei X., X. Kong, S. Wang, H.Xiang, J. Wang, J. Chen Removal of Heavy Metals from Electroplating Wastewater by Thin-Film Composite Nanofiltration Hollow-Fiber Membranes, Indust. Engin. Chem. Research, Vol. 52, No. 49, 2013, 17583-17590.

82. Zavarzin G.A., Microbial community in the past and present, Microbiol. J., Vol. 51, No. 6, 1989, 3-14.

83. Ziemiński K., M. Frąc, Methane fermentation process as anaerobic digestion of biomass: Transformations, stages and microorganisms, Afr. J. Biotechnol., Vol. 11, No. 18, 2012, 4127-4139.

84. Zonga W., R. Yu, P. Zhang, M. Fan, Z. Zhoub, Efficient hydrogen gas production from cassava and food waste by a two-step process of dark fermentation and photo-fermentation, Biomass and Bioenerg., Vol. 33, No. 10, 2009, 1458-1463.

85. Zverlov V. V., O. Berezina, G. A.Velikodvorskaya, W. H. Schwarz, Bacterial acetone and butanol production by industrial fermentation in the Soviet Union: use of hydrolyzed agricultural waste for biorefinery, Appl. Microbiol. Biotechnol., Vol. 71, 2006, 587-597.

\section{Researcher Vira Hovorukha, Ph.D. Ph.D. student Olesia Havryliuk \\ Leading engineer Iryna Sioma}

Zabolotny Institute of Microbiology and Virology of the NAS of Ukraine,

Department of Extremophilic Microorganism

Biology, room 224

154, Zabolotny str., Kiev, 03143, Ukraine

tel.: +380445263297

e-mails: vira-govorukha@ukr.net gav_olesya@ukr.net irasioma82@gmail.com 